\title{
VIRTUALIZATION OF EDUCATIONAL COMMUNICATIVE PRACTICES: GLOBAL TREND
}

\author{
Ryzhak L. V.
}

\section{INTRODUCTION}

At the beginning of the 1990s, highly developed countries started computerization and the informationalization of all spheres of social life. Doing so became possible due to the mass production of personal computers with user-friendly software. Over the following decade, the process has taken on the global dimension with the advent of the Internet. Its informational resources have provided unprecedented opportunities for electronic communication in the virtual Internet network space. As M. Kayku rightly remarked: "Every time a new system of communication emerged, it irrevocably accelerated change in society, transferring us from one era to another"1. M. Castells calls this new era the Internet Galaxy, in which social practices are implemented on the basis of a new model of sociability - the World Wide Web.

The use of the Internet as a communication system and organizational form during the last years of the second millennium is expanding like an explosion ${ }^{2}$. Networks have evolved into an organizational form that permeates all spheres of society. All across the board, economic, social, political and cultural are structured around the Internet and other computer networks. The Internet has ceased to be merely a system of accumulating, storing and transmitting the information. It is based on the virtual reality that exists in the artificial computer environment. Human-created virtual reality coexists and interacts with social reality. Moreover, virtual reality is becoming more and more active in the sphere of culture, education, leisure, and everyday life. This gave grounds to M. Castells to claim that we live in a "culture of real virtuality". It is virtual because it is built mainly on the technological processes of electronic communication ${ }^{3}$.

Already today, the human of the information society lives and realizes his opportunities in virtual reality, which expands social reality, and somewhat replaces it. In particular, D. Ivanov notes that if a person of an industrial

\footnotetext{
${ }^{1}$ Кайку М. Майбутнє розуму. Львів : Літопис, 2017. С. 117.

${ }^{2}$ Кастельс М. Інтернет-галактика. Міркування щодо Інтернету, бізнесу і суспільства. К. : Вид-во “Ваклер", 2007. С. 2.

${ }^{3}$ Кастельс М. Інтернет-галактика. Міркування щодо Інтернету, бізнесу і суспільства. К. : Вид-во “Ваклер”, 2007. С. 202-203.
} 
society finds themselves in social reality, perceiving it as a natural reality, in which it is necessary to live, then a person of a post-industrial society is immersed in virtual reality, fascinated by "living" in it, aware of its conditionality, controllability and the ability to leave it ${ }^{4}$.

At the beginning of the XXI century, virtualization became a global process, went beyond the economic and financial system and covered almost all spheres of social activity: politics, ideology, culture, education and lifestyle. Global computerization and informatization have drastically changed the rhythm and tempo of both personal and social life. It turned into a continuous competition between people, organizations and countries for mastering information and communication technologies, the complete information and knowledge. The leaders of the informational civilization compete for the "innovation resources", which ensure advanced development. "Today, - T. Friedman points out, - the key to wealth is how well your country or company collects, distributes and stores knowledge" ${ }^{5}$ and builds virtual reality.

The establishment of an informational society as the society of knowledge dictates new requirements to the education system, which must last throughout one's lifetime. This new paradigm requires new methodological grounds and the usage of information and communication technologies in a virtual environment. The innovative transformation of the education process encouraged philosophical reflection on the perspectives and consequences of high-tech upgrades in the communication environment of education, namely the opportunities and perspectives of virtualization of educational communicative practices, their impact on the quality, efficiency and accessibility of education.

\section{Virtual universities in global educational space}

The global computer-based virtualization of education began in the 1990s. This process was preceded by the following civilization tendencies:

- informatization of highly developed countries and the introduction of computer technologies in all spheres of social life, including in education;

- Internet that has brought together countries and continents through a computer network, changing the educational landscape;

- the formation of a global capitalist system with its free-market and liberal-democratic ideology. Market values have become a priority not only in business, finance and commerce, but also in education and culture.

\footnotetext{
${ }^{4}$ Иванов Д. Виртуализация общества. СПб.: "Петербургское Востоковедение”, 2000. C. 20.

${ }^{5}$ Фрідмен Т. Лексус і оливкове дерево. Зрозуміти глобалізацію. Львів: Б.в., 2002. C. 293.
} 
These trends characterize the transition of humanity to a global postindustrial society, whose main resource is knowledge. The importance of knowledge in the life of society has led to the priority of education that will last throughout one's lifetime. Continuing education is provided by universities that operate in the context of the emergence of global communicative space. The Global Internet allows one to design and build national education networks. With the help of computer and information technologies, such networks are open; they directly or indirectly interact with and influence one another, so there is a reason to ascertain the existence of global educational space.

In today's globalized world, leadership is being taken by countries that offer quality education, technological innovations and the use of computer networking technologies. The global educational space is a field of competition for the best entrants and sources of funding, for the accordance of education to society's expectations and social goals and needs, taking into account cultural development and the environment.

The virtualization of educational communicative practices was initiated by Open Corporate Universities, which implement various forms of remote e-learning. Some of the examples are "the British Open University", "the Spanish National University of Distance Education", "the Virtual Open University of Catalonia", the Educational and Information Consortium "Phantom" and more. These are business corporations, for which knowledge is a demanding product and for which potential consumers are prepared to pay. Virtual universities are also implementing business projects for the commercialization of education, not only within individual countries, but also at the global market level. Such business corporations are called by J. Heygel as formators, because they dictate the rules and ways of interaction in every sphere of activity, including in the educational sphere. While companies that learn and learn how to interact, belong to adapters ${ }^{6}$.

Corporate universities, as D. Dzvinchuk notes, are "virtual educational institutions that do not have columns and large amphitheater classrooms. Corporate higher education institutions are simply a group of professionals who have created their own electronic database and skillfully utilized other information resources, enabling them to offer consumers the required range of educational services" ". According to D. Dzvinchuk, virtual universities are the basis for the formation of a "global higher education", which offers a new vision of the learning process in a high-tech environment.

${ }^{6}$ Цит. за Фрідмен Т. Лексус і оливкове дерево. Зрозуміти глобалізацію. Львів: Б.в., 2002. C. 269-270.

7 Дзвінчук Д. Освіта в історико-філософському вимірі: тенденції розвитку та управління. К.: ЗАТ “Нічлава”, 2006. С. 173-174. 
The use of Internet resources by virtual universities was primarily about adapting innovative capabilities to traditional educational models that did not affect educational communicative practices. It should be noted that electronic databases were being created at the time, so online educational resources were limited. Therefore, students have traditionally acquired basic knowledge from the professors' textbooks or lecture materials shared via email. Virtual "communication" between teachers and students was based on the use of email. Information and knowledge were exchanged by sending a text or other materials to email boxes. Knowledge had to be mastered by students themselves since email is not a discussion platform that uses communicative practices.

The situation has changed dramatically due to the combination of the Internet with network technologies. They enabled virtual university students to work online, with access to information resources at all times. The specificity of virtual education is determined by the flexibility and interactivity of learning, network opportunities to discuss and consult with colleagues or experts, regardless of the country of residence, which is a distinct advantage of such universities. By the way, the first virtual universities emerged in the US. The Virtual High School project was developed by the University of Massachusetts, which conducts research on the use of new technologies in the learning process. It is an American project of "brilliant education", based on which the training of specialists is cheap, fast and efficient ${ }^{8}$. The purpose of this project is to teach effectively in the virtual environment using freely available content from around the world.

The undoubted advantage of virtual universities is the increase in the number of students due to the lack of space and time constraints in education and a moderate fee. Such benefits have been made possible by the Internet, which, according to M. Castells, provides a new model of communication in our societies. It is characterized by network individualism ${ }^{9}$. Therefore, the principle of privatization of communication skills is based on the educational practices of virtual universities. It allows one to individually develop a strategy for studying courses based on one's professional needs and personal interests. Usually, the strategy is aimed at upgrading skills and getting acquainted with new scientific achievements in the professional field. Therefore, highly specialized training courses encourage professional activity. Despite the fact that virtual universities provide market-based educational services, they, as D. Dzvinchuk rightly points out, have a distinct "tutoring"

\footnotetext{
${ }^{8}$ Квєк М. Національна держава, глобалізація та Університет як модерний заклад // В кн. Ідея Університету: Антологія. Львів : Літопис, 2002. С. 269-294.

${ }^{9}$ Кастельс М. Інтернет-галактика. Міркування щодо Інтернету, бізнесу і суспільства. К. : Вид-во “Ваклер”, 2007. С. 129.
} 
purpose $^{10}$. Instead, personal development remains unaddressed. However, not only does a modern educated person acquire professional competences and knowledge, they assert themselves as a moral personality and a socially engaged citizen responsible for their actions. An educated person cannot be formed outside the social community, including the university community, with its academic values and freedoms.

However, today, as M. Castells states, the dominant tendency in the development of social relations in our societies is the growth of individualism in all its manifestations. A model of the virtual university as a personalized community, centered in "self-centered" networks, has been built on the basis of communicative-network individualism. Each virtual university student has the opportunity to build an online network based on their own professional interests. In the educational process, virtual interaction on the implementation of educational projects is possible. However, sociocultural interaction is unlikely. As J. Baudrillard points out, the point is that the virtual is the sphere where all events take place in technological mode, so "there is no value in the virtual simple informativeness, calculation, computability dominates" ${ }^{\prime 11}$. Therefore, virtual communicative practices do not require them to show their personality, values and beliefs. Virtual universities are primarily designed to shape the business elite, its cosmopolitan culture and a cosmopolitan worldview.

Virtual universities, like their sponsors - transnational corporations - are geared toward cosmopolitan identity, because in modern education, the specialization and professional identification of individuals who ensure their mobility and competitiveness in the global labor market are highly valued. Immersed in their narrow professional problems, specialists do not feel responsible for the future generations for the consequences of scientific and technological innovations. Their cosmopolitanism is devoid of obligations to the national community; they do not identify with it. This can be explained by the increase in the number of students in virtual universities.

Thus, according to UNESCO, in 2001, there were 1,180 virtual universities. According to expert estimates, the number of students enrolled in virtual universities in 2020 will exceed the number of students of classical universities $^{12}$. This means that classical universities are forced to compete with virtual universities for students and therefore have to offer quality education using online networking technologies.

10 Дзвінчук Д. Освіта в історико-філософському вимірі: тенденції розвитку та управління. К.: ЗАТ “Нічлава”, 2006. С. 31.

${ }^{11}$ Бодрияр Ж. Пароли. От фрагмента к фрагменту. Екатеринбург: У-Фактория, 2006. C. 32 .

12 Всемирный доклад ЮНЕСКО 2005 http://unesdoc.unesco.org/images/0014/001418/ 141843r.pdf C. 94. 


\section{Classic universities: the challenges of global virtualization}

Unlike a virtual university, a classical university is territorially occupied. It functions institutionally on the territory of the nation-state and, as an educational institution, enters the global space of education. In the 1960s, K. Jaspers wrote: "The university accomplishes its task - scientific research, training, education, communication, and the implementation of scientific ideas - within the institution. To do so, it needs buildings, scientific material, textbooks, institutes, and administration of these objects"13.

The task of the university was and remained not only the training of a professional at the level of modern science and technology, but also the formation of a human personality as a citizen who identifies with the national community.

The implementation of the educational and scientific mission by a classical university has encountered a number of challenges. Firstly, it is a challenge of market fundamentalism, on the basis of which virtual universities operate. Global competition is pushing classic universities to move to business as well. Secondly, it is a challenge to the national rootedness of the classical universities, which have fulfilled the mission of forming the national elite, preserving and transmitting not only knowledge, but also social and national memory, national traditions etc. Thirdly, it is a challenge to the national educational elite with its mentality, personalized knowledge, individual experience, academic freedoms, and values. In the new world of "academic capitalism", as V. Gorokhov states, there is no place for the classic role of professor and scientist. Scientific research and teaching are replaced by the function of increasing the symbolic and monetary capital of academic entrepreneurship $^{14}$. Therefore, today, "scientific managers" who are able to attract sponsorship finance are more appreciated than the intellectual potential of a scientist and their teaching abilities.

At the same time, a new paradigm of education has emerged - the need and ability to learn throughout life. This educational strategy for the future is made possible by the virtualization of education and its information and computer technology. However, "Internet-based learning, as M. Castells emphasizes, is not only a matter of technical skill; it is changing the type of education required to work online, as well as to develop the capacity to learn in the Internet-based economy and society... The decisive issue is shifting the focus from studying to ability to learn, since most information is online, and

${ }^{13}$ Ясперс К. Ідея Університету // В кн.: Ідея Університету: Антологія. Львів : Літопис. 2002. C. 161.

${ }^{14}$ Горохов В. Как возможны наука и научное образование в эпоху “академического капитализма"? // Вопросы философии, 2010. № 12. С. 4. 
what is really needed is the ability to decide what to look for, how to get it, how to handle it, and how to use it for a specific task. In other words, new learning is focused on developing the ability to learn to transform information into knowledge and knowledge into action"

Unlike virtual universities, classical universities are educational and research complexes, in which professors carry out scientific research, involving students in laboratory experiments, research projects, grants, and more. Universities must combine the teaching of scientific knowledge with the use of information and computer technologies in natural, socio-economic, and humanities sciences to meet the requirements of today. Thus, virtualization applies not only to educational communicative practices, but also to research. Modern science, according to D. Ivanov, is not a search for truth, but manipulation of models of scientific discourse. Science emerges as a permanent process of constructing alternative models and their computer simulation ${ }^{16}$. By participating in scientific research, the student acquires not only modern scientific knowledge, but also acquires professional and sociocultural competences.

Undoubtedly, education in the information society must be innovative and competitive, ensuring the mobility of graduates in the labor market. However, this is not a priority goal of education. The competence of the specialist is, of course, important, but it should serve the spiritual and intellectual development of the person and the balanced socio-economic and environmental progress of the country. As the rector of Kyiv-Mohyla Academy V. Bryukhovetskyy correctly pointed out, one can teach everything by making some efforts, but one cannot learn two things: first -talent and second - love for freedom. According to him, universities also cannot teach this. However, "only in universities can you create the conditions, in which a person will discover their talent and understand what it is. And it is possible to create such conditions when a person feels the taste of freedom: as the bud opens, so will the person suddenly realize what a great good it is to be free. To speak and act the way you want, within the bounds of obvious social norms and rules, but the way you want, not the way you are told. These two things can only be done by a real university" ${ }^{\prime 17}$.

Freedom cannot be given to students in the form of ready-made knowledge that must be remembered. They should be taught about it

${ }^{15}$ Кастельс М. Інтернет-галактика. Міркування щодо Інтернету, бізнесу і суспільства. К. : Вид-во “Ваклер”, 2007. С. 259-260.

${ }^{16}$ Иванов Д. Виртуализация общества. СПб.: "Петербургское Востоковедение", 2000. C. 54.

${ }^{17}$ Брюховецький В. Києво-Могилянська академія: десять років відновлення // Вища школа, 2001. № 2-3. С. 20. 
throughout their studies. Actually, then, the freedom to study and to be responsible for the results of your studies, freedom to communicate and to make your own decision will become an essential feature of an educated person. Therefore, the most important task of the university is to form the level of freedom, at which a person carries out his or her own life project in the form of a social contribution.

In fact, the classical university seeks to develop human talents. Their identification is precisely made by direct communication with the professors, which strongly influences the way of thinking and the way of acting on the formation of students' critical and creative potential.

It is clear that the use of the latest technologies in the educational process will change the functions of the professor, but not displace them. It is an illusion that virtual universities present communicative practices without a professor. After all, the creation of virtual content is the responsibility of the professor, namely the preparation of electronic dictionaries, lectures and textbooks, as well as the maintenance of personal educational and professional networks. The Internet only digitizes and formats the information provided. Instead, the content of electronic resources, updating them with scientific achievements, is the responsibility of the professor. The professor is also responsible for the interactive development of the virtual educational network: the dialogues of knowledge presentation, questions that need to be answered independently, motivation to educate yourself.

Responding to challenges and queries, classic universities offer a mixed model of education, in which traditional classroom lessons are complemented by virtual communicative practices. Education is not only a transfer of knowledge, but also the development of personality. Knowledge is rapidly morally maturing, which is why it is so important to acquire competencies that will allow you to navigate not only in your professional activity, but to live on top of your time.

It should be noted that access to virtual educational content does not guarantee the development of competencies. Only in the process of direct communicative practices, analytical skills and critical thinking are formed and professional knowledge acquires a personal-cultural sense and social importance in society. Therefore, only some of the basic courses can be replaced by electronic courses. Therefore, in a classical university, the principle of complementarity, not a substitution, prevails in the educational process.

Today it can be stated that professors and students are actively using virtual content in the educational process. In particular, they use electronic dictionaries, reference books, tutorials, and lecture courses for the organization of students' independent work and its individualization. 
It is impossible not to notice, as J. Baudrillard writes, that today there is an undisguised attraction to virtual and related technologies ${ }^{18}$. The use of virtual technologies in education is ambiguously evaluated by scientists. In particular, American philosophers, sociologists, and experts are optimistic about the computerization of learning, while European intellectuals are skeptical. This is due, in particular, to the fact that computerization universalizes linguistic means of expressing thoughts and feelings. The algorithmic computer interaction language is being transmitted to the human communication system. It is simplified because its language has only one meaning, which is unified and understandable to most people. The vocabulary is simplified, which inevitably affects the thinking style, its over-rationalization, and computer dependency. A new type of rationality is emerging - computer rationality ${ }^{19}$. Computer savviness is represented by powerful informationretrieval systems that are easy to use, high-speed, and provide interactive networking. Through information retrieval systems, the student is immersed in an artificially created virtual world, also called hyperreality.

One of the caveats about overusing computerization of learning may be the phenomenon of hypertext as a representative of a textbook. Hypertext does not have a clear structure, but only contains an infinity of transitions between fragments of text. Hypertext is characterized by a lack of continuity - a jump: the unexpected movement of a user's position in the text. Yes, the user can continue text, "jump" from one fragment to another, and even add and rewrite the text, develop storylines. Computer text is a field of creativity that does not require a thorough mastery of knowledge. An illustrative example is the operation of Wikipedia, in which information is fragmented, without citing sources. Anyone can supplement its contents without guaranteeing the accuracy of knowledge. The transformation of Wikipedia content, even before its distortion, increases the user's ability to acquire fragmentary knowledge.

If the textbook, as systematically assembled by the teacher, requires analytical and synthetic thinking from the student, then the computer-based presentation of the book, accompanied by audiovisual elements, may impose on the individual fragmentary and figurative perception of information that is insufficiently controlled.

The fragmentation of the student's thinking is a threat to the holistic existence of man and an urgent problem of modern education. In all modern philosophical concepts of education, it is necessary to form coherent thinking. Obviously, this is not a fluke, but a challenge of time. The fact is that the basis

\footnotetext{
19 Миронов В. Коммуникационное пространство как фактор трансформации современной культуры и философии // Вопросы философии, 2006. № 12. С. 28.
} C. 31 .

${ }^{18}$ Бодрияр Ж. Пароли. От фрагмента к фрагменту. Екатеринбург: У-Фактория, 2006. 
for the integrity of thinking is the biological interconnectedness of the left and right brain functions. The book "integrates" both functions: speech-verbal and figurative-visual, while computer-network technologies involve only figurative-visual thinking. The communicative fragmentation of Internet information at the level of personal consciousness is not always realized.

This is why professors are concerned about overusing computerization and informatization of educational practices. Access to information resources does not mean spontaneous learning. This requires analytical thinking, which is formed in the process of communicative development of intellectual experience. Such experience is the impersonal knowledge of the professor. In the educational process, as V. Pashkov emphasizes, the professor uses "the whole arsenal of intellectual and psycho-emotional means that make up his personality: reflection, empathy, intuition, metaphor, imagination, creativity, humanitarianism and humanity, multiculturalism" 20 . It is clear that the unique personal experience of a professor cannot be digitized and transmitted to a computer.

Therefore, the introduction of technological innovations should take into account the potential consequences for humans and their habitat. That is why humankind has to come up with ethical and environmental mechanisms to define technology and within what limits to master. Such mechanisms present socio-cultural practices (traditions, rules, norms) produced by humanity on the basis of socio-humanitarian knowledge.

\section{Virtualization of university education in Ukraine}

Informatization of education in Ukraine began in the mid-1990s. An informatics course was introduced into the educational process, the purpose of which is to study programming languages and to develop students' computer literacy ${ }^{21}$. Unfortunately, at that time, there was no mass access to personal computers for use in the educational process. Standard computer classes only appeared in the early $21 \mathrm{st}$ century. The computerization of education has become a reality. The use of personal computers has made it possible to innovate the learning process through the development of smart learning systems. Such systems do not take over the routine functions of information retrieval, its classification and systematization, calculations, etc. Since 2010, the process of introducing the Internet to the educational process has started with the use of open-source Internet resources.

\footnotetext{
${ }^{20}$ Пашков В. Віртуалізація освіти: пріоритети і ризики // Гілея: науковий вісник, 2014. Вип. 86. С. 288.

${ }^{21}$ Биков В. Інформатизація освіти // Енциклопедія освіти України. - К.: Юрінком Інтер, 2008. C. $360-362$.
} 
It should be noted that the processes of computerization and introducing the Internet to the education in Ukraine are lagging behind, first and foremost, technically and technologically, due to the lack of high-speed Internet, modern personal computers and licensed software.

Education virtualization is technologically supported by LANs connected to the WAN. It is clear that having access to the Internet and local area networks does not guarantee their efficient use. The potential of the Internet, as M. Castells says, can only be used by those who have digital competencies $^{22}$.

Introducing digitization to education is the primary task of its reform in Ukraine. Creating digital content in open access involves, first and foremost, the formation of the digital, cognitive and linguistic competences of educators. That is why the Ministry of Education and Science of Ukraine is implementing the National Digital Literacy Program since 2020. The online program has already started to operate. The acquisition of digital competencies will help to create educational websites in the Ukrainian language.

However, in order to compete successfully in the global virtual environment, it is necessary to present training resources in one of the foreign languages (English, German, Spanish). Linguistic competence, knowledge of at least one European language, is a prerequisite for both students and professors. The fact is that Lviv National University (LNU) is actively involved in student mobility programs (Erasmus and Erasmus +). However, for the time being, students of LNU have the opportunity to study, according to the agreements, in fifteen European universities. At the same time, the university has limited opportunities to enroll foreign students for mobility programs due to the lack of educational content in the English language.

The faculties of Lviv National University implements the principle of complementarity of direct communication with virtual communicative practices. To do this, professors use the special features of the Moodle platform. It allows to individualize the learning process, offer each student a personal strategy of individual learning, expanding the opportunities for independent work of the student in the form of presentations, essays, projects, simulation modeling.

Local area networks become training grounds for exploration in a new knowledge environment. In particular, the use of online and computer-based technologies in education opens up new opportunities for self-organization in the educational process. The examples of such a phenomenon are, on the one

22 Кастельс М. Інтернет-галактика. Міркування щодо Інтернету, бізнесу і суспільства. К. : Вид-во “Ваклер”, 2007. С. 248. 
hand, the exchange of knowledge vertically (professor-student), under the control of the professor, and on the other, the exchange of information resources horizontally (student-student).

Developed online courses on the Moodle platform provide students with pre-written texts that are necessary for effective audience work. Having online content does not require students to record lectures and focus on memorizing content. The lecture can be constructed as a dialogue, as a hermeneutical comprehension of the meaning of the read texts. Thus, models of educational and communicative practices are changing.

The accelerated development of innovative technologies and their impact on the virtualization of education cannot be predicted. Indeed, in twenty years, the use of computer and Internet technologies has changed dramatically, including the development of gadgets (smartphones, tablets, phones).

A cloud office platform was introduced at Lviv National University, which makes it possible to use gadgets for testing and recording a lecture during its presentation, not only directly in the audience, but also at a distance. This promotes the students' independent work on the course. However, an important specificity of development is being lost - interactivity, namely the ability to engage in dialogue, ask questions, clarify the content of knowledge and interpret, which allows gaining understanding.

With the invention of smartphones with the operating system, humanity has got a pocket-size personal computer that allows one to work not only with textual information, but with audio and visual elements, as well. Such smartphones are called communicators, which offer a wide range of smart technologies. They are becoming a priority in education, as they provide digital services of a wide range and personalize the process.

The benefits of virtualization of educational communicative practices should be combined with the development of the ability to communicate directly and reach agreement or compromise, which is important in teamwork. It is especially important to prevent communicative misunderstandings that are achieved by fostering a communicative culture, not just by mastering knowledge or competence.

A similar view was expressed by T. Friedman. The Internet and computers are great tools that "may help you think, but don't make you smart. They can search and find, but they can't reason. They may allow you to interact extensively with others, but they will not teach you how to be a good neighbor. They can help you look into the lives of many people, but they cannot advise you how to behave in a particular situation. This is the pedagogical paradox of the Internet. The faster your child's modem is, the faster it can go online and the more powerful its internal software should be if you want it to be successful. But internal software can only be written by good 
old methods: emphasis on the need to read, write and count, go to church, take care of the family. These things cannot be downloaded from the Internet; only parents and teachers can install them" 23 .

It is clear that Internet networking technologies are not neutral. They can both improve the quality of people's lives and be dangerous, even on a planetary scale. Humanity, according to J. Naisbitt, must "learn to live humanly in the age of high technology" for the sake of self-preservation and dignified life. As for the humanization of educational communicative practices, according to J. Naisbitt, humanity must "recognize that art, literature, dramaturgy, religion, science and time are equal partners in the development of technology... These spheres of human existence express what it means to be human and help to apply technology in a way that makes good use of its achievements" 24 .

The President of the Academy of Pedagogical Sciences of Ukraine V. Kremen emphasizes: "Of course, we do not want humanity to be united only by the Internet, without any system of values, without filters, without any concept of meaning, alternative to business and without any alternative view of people, different from the one that views them as consumers seeking the lowest price" 25 . People are unified and united, above all, by national and cultural elements: ideals, values, symbols, traditions, which are transmitted by the classical university from generation to generation. They serve as the basis for national identity, dignity and self-respect. Therefore, in the context of global virtualization of education, the university must nurture an intellectual elite rooted in the socio-cultural life of the nation, whose purpose is sustainable development in combination with scientific, technological and spiritual-intellectual progress.

\section{CONCLUSIONS}

The innovative use of Internet network resources and information and computer potential in the educational process led to its virtualization. In a quarter of the century, the virtualization of education has become a global trend of the 21 st century. The virtualization of education is a demand of time, a response to the challenges of today. It aims to optimize educational activities: promptly find, organize and analyze information. At the same time, the virtualization of communicative and educational practices is

${ }^{23}$ Фрідмен Т. Лексус і оливкове дерево. Зрозуміти глобалізацію. Львів: Б.в., 2002. C. 613.

${ }^{24}$ Нейсбит Дж. Высокая технология, глубокая гуманность : Технология и наши поиски смысла. М. : АСТ : Транзиткнига, 2005. С. 41.

${ }^{25}$ Кремень В. Філософія людиноцентризму в освітньому просторі. К.: Т-во Знання України, 2010. С. 284. 
imperceptible, but it steadily replaces direct communication, not only in the educational process, but also beyond its boundaries. Undoubtedly, virtual communicative practices intensify the development of the intellectual potential of professors and students. However, something is lost; namely, students' emotional potential is not developing. After all, its development is carried out only through direct communication. In such cases, the intellect is supplemented by emotions and imagination, on the basis of which creative thinking is formed.

\section{SUMMARY}

The tendencies of globalization in education and their social-civilizational preconditions are examined. The essence and peculiarities of the virtualization of education in the context of technological innovations are clarified. It is shown that the formators of virtualization of educational and communicative practices are corporate (virtual) universities, which operate on the basis of market values. Transformations of educational communicative practices are explored: mass computerization of learning, online networking of knowledge and intellectual experience, individualization of educational communicative through gadgets. The problems of virtualization of educational communicative practices in Ukraine are analyzed: lack of high-speed Internet, modern computers, software, as well as digital competences of participants of the educational process. Digitization in education is the primary task of reforming education in Ukraine. It is argued that the synergy of high technology and digital competencies is the key to the innovative transformation of education and the virtualization of educational communicative practices.

\section{REFERENCES}

1. Биков В. Інформатизація освіти // Енциклопедія освіти України. К.: Юрінком Інтер, 2008. С. 360-362.

2. Бодрияр Ж. Пароли. От фрагмента к фрагменту. Екатеринбург: УФактория, 2006. 200 с.

3. Брюховецький В. Києво-Могилянська академія: десять років відновлення // Вища школа, 2001. № 2-3. С. 3-21.

4. Всемирный доклад ЮНЕСКО “К обществам знания" 2005 г. http://unesdoc.unesco.org/images/0014/001418/141843r.pdf

5. Горохов В. Как возможны наука и научное образование в эпоху “академического капитализма”? // Вопросы философии, 2010. № 12. С. 3-14.

6. Дзвінчук Д. Освіта в історико-філософському вимірі: тенденції розвитку та управління. К.: ЗАТ “Нічлава”, 2006. 378 с.

7. Иванов Д. Виртуализация общества. СПб.: "Петербургское Востоковедение”, 2000. 96 с. 
8. Кайку М. Майбутнє розуму. Львів : Літопис, 2017. 408 с.

9. Кастельс М. Інтернет-галактика. Міркування щодо Інтернету, бізнесу і суспільства. К. : Вид-во "Ваклер”, 2007. 304 с.

10. Квєк М. Національна держава, глобалізація та Університет як модерний заклад // В кн. Ідея Університету: Антологія. Львів : Літопис, 2002. C. 269-294.

11. Кремень В. Філософія людиноцентризму в освітньому просторі. К.: Т-во Знання України, 2010. 520 с.

12. Миронов B. Коммуникационное пространство как фактор трансформации современной культуры и философии // Вопросы философии, 2006. №12. С. 27-43.

13. Нейсбит Дж. Высокая технология, глубокая гуманность: Технология и наши поиски смысла. М.: АСТ: Транзиткнига, 2005. 381 с.

14. Пашков В. Віртуалізація освіти: пріоритети і ризики // Гілея: науковий вісник, 2014. Вип. 86. С. 288-291.

15. Робінсон К. Освіта проти таланту. Сила творчості. Львів: Літопис, 2017. $256 \mathrm{c}$.

16. Фрідмен Т. Лексус і оливкове дерево. Зрозуміти глобалізацію. Львів: Б.в., 2002. 624 с.

17. Ясперс К. Ідея Університету // В кн.: Ідея Університету: Антологія. Львів: Літопис. 2002. С. 111-165.

Information about the author: Ryzhak L. V., Ph.D., Associate Professor at the Department of Philosophy, Ivan Franko National University of Lviv 1, Universytetska str., Lviv, 79000, Ukraine 